\title{
EFFECT OF FLAVONOIDS ON OXIDATIVE STRESS, APOPTOSIS, AND CELL MARKERS OF PERIPHERAL BLOOD-DERIVED ENDOTHELIAL PROGENITOR CELLS: AN IN VITRO STUDY
}

\author{
WAHYU WIDOWATI ${ }^{*}$, RIMONTA F. GUNANEGARA ${ }^{1}$, TERESA LILIANA WARGASETIA ${ }^{1}$, HANNA SARI WIDYA \\ KUSUMA ${ }^{2}$, SEILA ARUMWARDANA ${ }^{2}$, CINTANI DEWI WAHYUNI ${ }^{2}$, ERMI GIRSANG ${ }^{3}$, I NYOMAN EHRICH LISTER ${ }^{3}$, \\ CHRISMIS NOVALINDA GINTING ${ }^{3}$, RIZAL RIZAL ${ }^{2,4}$, INDRA BACHTIAR ${ }^{5}$, HARRY MURTI ${ }^{5}$, YOUNG HO KIM$^{6}$
}

\begin{abstract}
${ }^{1}$ Faculty of Medicine, Maranatha Christian University, Bandung 40164, West Java, Indonesia, ${ }^{2}$ Biomolecular and Biomedical Research Center, Aretha Medika Utama, Bandung, 40163, West Java, Indonesia, ${ }^{3}$ Faculty of Medicine, Universitas Prima Indonesia, Medan 20118, North Sumatera, Indonesia, ${ }^{4}$ Biomedical Engineering, Department of Electrical Engineering, Faculty of Engineering, Universitas Indonesia, Depok 16426, West Java, Indonesia, ${ }^{5}$ Stem Cell and Cancer Institute, Jakarta, 13210, Indonesia, ${ }^{6}$ College of Pharmacy, Chungnam National University, Republic of Korea

Email: wahyu_w60@yahoo.com
\end{abstract}

Received: 16 Sep 2020, Revised and Accepted: 09 Oct 2020

\begin{abstract}
Objective: Circulating EPCs (endothelial progenitor cells) play a role in neovascularization and vascular repair. Oxidative stress impairs endothelial progenitor. Flavonoid is a phytochemical compound for antioxidant activity. Flavonoid effects toward oxidative stress, apoptosis, and expression of the cell markers on EPCs are not fully understood. This study was aimed to elucidate the effects of quercetin, kaempferol, and myricetin toward oxidative stress, apoptosis, and cell markers of peripheral blood-derived-EPCs.
\end{abstract}

Methods: EPCs (endothelial progenitor cells) were isolated from peripheral blood mononuclear cells (PBMNCs) using cultivation under EPCs spesific media. Oxidative stress in EPCs was induced by $\mathrm{H}_{2} \mathrm{O}_{2}$ and then treated by quercetin, kaempferol, and myricetin. Cytotoxicity was measured by 3-(4,5-dimethylthiazol-2-yl)-5-(3-carboxymethoxyphenyl)-2-(4-sulfophenyl)-2H-tetrazolium (MTS) assay, while intracellular reactive oxygen species (ROS), apoptosis and characterization of cells, which expressed CD133 and KDR, was measured using flow cytometry.

Results: Quercetin, kaempferol, and myricetin at concentration $12.50 \mu \mathrm{mol} / \mathrm{l}$ were not toxic on EPCs as the cells viability were $96.11 \pm 4.03 \%$, $95.42 \pm 7.75 \%$, and $94.22 \pm 9.49 \%$, respectively. Flavonoids decreased intracellular ROS level in EPCs (quercetin: 14.38 $\pm 1.47 \%$, kaempferol: $20.21 \pm 6.25 \%$, and myricetin: $13.88 \pm 4.02 \%)$ compared to EPCs treated with $\mathrm{H}_{2} \mathrm{O}_{2}(30.70 \% \pm 1.04)$. Percetage of EPCs apoptosis was not significantly different among each treatment. Immunophenotyping showed the increasing of CD133 and KDR expression in EPCs treated with flavonoids.

Conclusion: Quercetin, kaempferol, and myricetin were safe for EPCs, decreased ROS levels, and increased CD133 and KDR expression. However, the flavonoids did not significantly affect EPCs apoptosis.

Keywords: Apoptosis, Endothelial progenitor cells, Flavonoids, Reactive oxygen species

(C) 2021 The Authors. Published by Innovare Academic Sciences Pvt Ltd. This is an open access article under the CC BYlicense (https://creativecommons.org/licenses/by/4.0/) DOI: https://dx.doi.org/10.22159/ijap.2021.v13s3.07 Journal homepage: https://innovareacademics.in/journals/index.php/ijap

\section{INTRODUCTION}

Endothelial progenitor cells (EPCs) are bone marrow-derived cells that can be found in peripheral blood. EPCs promote neovascularization and indirectly regulate local endothelial cells' angiogenic functions [1]. Through this action, EPCs are involved in vascular repair and their impairment leads to an increase risk of various vascular endothelial and cardiovascular dysfunction [2]. Several factors, including oxidative stress, contribute to the development of endothelial dysfunction through EPCs senescence [3]. Oxidative stress impairs EPCs function by activating downstream pathways leading to cellular senescence or apoptosis [4]. Oxidative stress can lead the apoptosis by mitochondrial signaling pathway $[5,6]$ and cellular senescence by activated DNA damaging response pathway [7].

Flavonoids are phytochemical compounds readily available in daily human diet with a wide range of biological activities. Kaempferol, quercetin, and myricetin are members of flavonoid flavonol class that can be found easily in fruits and vegetables. This type of flavonoids is known for numbers of biological activities, including antioxidant, antidiabetic, antiinflammatory, and many others [8-10]. Population studies found that consumption of food rich in flavonoid was related with decreased risk of cardiovascular health problem [11]. The mechanism of flavonoid in decreasing cardiovascular health problem is likely involving more than one pathway, including antioxidant and anti-inflammatory function and vascular effect [12]. Benefit of flavonoids was likely due to their interaction with endothelial cells and EPCs. For example, quercetin is taken up rapidly in cell and accumulated mostly in mitochondria. Intra- mitochondrial quercetin appears to prevent mitochondrial disfunction as well as for the redistribution to cytosol, if flavonoid fraction retained in cell is consumed progressively either by cell-permanent oxidants such as peroxynitrite or by activation of plasma membrane oxidoreductases [13].

A previous study demonstrated the ability of green tea extract, tea catechins including catechin (C), epigallocatechin (EGG), epicatechin gallate (ECG) and epigallocatechin gallate (EGCG) to protect EPCs from cellular injury through reduction of intracellular reactive oxygen species (ROS) $[14,15]$. More studies are required to investigate whether other groups of flavonoids may posses similar properties. Another study showed that quercetin treatment was able to ameliorate EPCs number [15]. Despite those facts, the effects of quercetin, kaempferol, and myricetin toward cellular injuries and several important endothelial markers are unkown. Based on the protective properties of flavonoids against free radicals, this research aimed to investigate the effect of quercetin, kaempferol, and myricetin on oxidative stress, apoptosis, and cell markers of peripheralblood-derived-EPCs.

\section{MATERIALS AND METHODS}

\section{Materials}

Human blood samples $(n=3)$ were provided by healthy human volunteers. The EPCs were characterized based on the binding of lectin Ulex europaeus agglutinin-1 (FITC-UEAI) (Sigma-Aldrich, USA) and uptake of acetylated-low density lipoprotein (DiI-Ac-LDL) (Sigma-Aldrich, USA). 2'-7'-dichlorofluorescein diacetate (DCF-DA), 4',6-diamidino-2-phenylindole (DAPI) (Invitrogen, USA), Ficoll- 
Paque (GE Healthcare, Sweden), human fibronectin (Roche, Switzerland), VascGrow ${ }^{\mathrm{TM}}$ medium (Stem Cell and Cancer Institute, Indonesia), Fc Receptor (FcR) blocker (Miltenyi Biotec, Germany), CD133 PE (Miltenyi Biotec, Germany), VEGFR2/KDR/Flk-1 PE (RandD System, USA). quercetin, kaempferol, myricetin used from (Biopurify Phyto-chemical, China).

\section{Methods}

\section{Isolation and culture}

Human blood samples $(n=3)$ were provided by healthy human volunteers. All volunteers signed an informed consent prior to blood collection. Ficoll-Paque density gradient centrifugation was employed to isolate total peripheral blood mono-nuclear cells (PBMNCs) from peripheral blood samples. PB-MNCs were cultured for 7 $\mathrm{d}$ in culture dishes, which were coated with human fibronectin, in VascGrow $^{\mathrm{TM}}$ medium (Stem Cell and Cancer Institute, Indonesia) at $37{ }^{\circ} \mathrm{C}$, humidified, and $5 \% \mathrm{CO}_{2}$ to get EPCs that were used in the experiments $[14,15]$.

\section{EPCs functional characterization}

The EPCs was characterized based on the binding of lectin Ulex europaeus agglutinin-1 (FITC-UEAI) and uptake of acetylated-low density lipoprotein (DiI-Ac-LDL) $[14,15,17]$. Cultured cells were incubated in DiI-Ac-LDL $(1 \mathrm{mg} / \mathrm{ml})$ at $5 \% \mathrm{CO}_{2}, 37^{\circ} \mathrm{C}$ for $4 \mathrm{~h}$. The cells were then fixed for $10 \mathrm{~min}$ with paraformaldehyde (3\%). Then, the cells were washed and incubated at $37^{\circ} \mathrm{C}$ for $1 \mathrm{~h}$ using FITC-UEAI $(1$ $\mathrm{mg} / \mathrm{ml}$ ). The nucleus staining was done using 2'-7'dichlorofluorescein diacetate (DCF-DA) and 4',6-diamidino-2phenylindole (DAPI). The cells both positive FITC-UEA-I and Dil-ac LDL were characterized as EPCs $[14,15]$.

\section{Cytotoxicity assay}

Cytotoxicity of quercetin, kaempferol, and myricetin (Biopurify Phyto-chemical, China) toward isolated EPCs were measured using MTS (Promega, USA) assay. EPCs $\left(5 \times 10^{3}\right)$ were inoculated with serum-free medium in 96-well plates then incubated at $37{ }^{\circ} \mathrm{C}, 5 \%$ $\mathrm{CO}_{2}$ for $24 \mathrm{~h}$. The EPCs were treated using different concentrations $(100 ; 50 ; 25 ; 12.5 \mu \mathrm{mol} / \mathrm{l})$ of quercetin, kaempferol, and myricetin that were diluted in dimethyl sulfoxide (DMSO). MTS was then added and incubated at $37{ }^{\circ} \mathrm{C}, 5 \% \mathrm{CO}_{2}$ for $4 \mathrm{~h}[9,10,14,15]$. The absorbance were measured using a microplate reader with $490 \mathrm{~nm}$ wave length (Biorad, USA).

\section{Intracellular ROS assay}

EPCs $\left(5 \times 10^{5}\right)$ were inoculated with serum-free medium in 6-well plates then incubated at $37{ }^{\circ} \mathrm{C}$, humidified, and $\mathrm{CO}_{2} 5 \%$. EPCs were treated with quercetin, kaempferol, and myricetin $(12.5 \mu \mathrm{mol} / \mathrm{l})$ diluted in DMSO for 24 h. Oxidative stress in EPCs was induced using $\mathrm{H}_{2} \mathrm{O}_{2}$ treatment. $\mathrm{H}_{2} \mathrm{O}_{2}$ treated cells and cells without treatment were used as positive and negative controls, respectively. EPCs were then harvested and stained with DCF-DA $(10 \mu \mathrm{mol} / \mathrm{l})$ at $37^{\circ} \mathrm{C}$, humidified, and $\mathrm{CO}_{2} 5 \%$ for $30 \mathrm{~min}$. The stained cells were washed with PBS containing $\mathrm{KCl}$ solution. FACSCalibur flowcytometry was used to measured the levels of intracellular ROS (Becton Dickinson, USA) $[14,15]$.

\section{Apoptosis assay}

EPCs $\left(5 \times 10^{5}\right)$ were inoculated in 6-wells with serum-free medium and incubated for $24 \mathrm{~h}$ at $37{ }^{\circ} \mathrm{C}, 5 \% \mathrm{CO}_{2}$. EPCs were treated with, kaempferol, quercetin, and also myricetin $(12.5 \mu \mathrm{mol} / \mathrm{l})$ diluted in DMSO and incubated for $24 \mathrm{~h}$. The EPCs were harvested, diluted in PBS, and stained with propidium iodide (PI) for 15 min. FACSs Calibur flowcytometry was used to determine the apoptotic cells as SubG1. The apoptotic cells were determined based on a broad hypodiploid (sub-G1) peak [15, 18].

\section{Immunophenotyping}

Flavonoid treated EPCs were harvested and incubated with Fc Receptor (FcR) blocker at room temperature for $15 \mathrm{~min}$. The EPCs then were incubated with each of the following fluorochrome conjugated antibodies: CD133 PE (Miltenyi Biotec, Germany), and VEGFR2/KDR/Flk-1 PE. Expression for each surface marker was analyzed using a FACS Calibur flowcytometry. Calculation of the percentage of markers was done based on percentage reduction of markers with the isotype using BD Cell QuestTM Pro software (Becton Dickinson, USA) [14, 15].

\section{Statistical analysis}

Data were depicted as mean \pm standard deviation. Statistical analysis of the data was evaluated using SPSS software. ANOVA (One-way Analysis of Variance) followed by Duncan post-hoc test was performed to evaluate the statistical significance between the three flavonoid treatments. The result is considered as significant if the Pvalue was lower than 0.05 .

\section{RESULTS AND DISCUSSION}

In this study, the effect of flavonols commonly found in dietary source: quercetin, kaempferol, and myricetin on cellular injury in EPCs were examined. EPCs were isolated from peripheral blood mononuclear cells (PBMNCs) using cultivation under EPCs specific media. PB-MNCs were cultured and isolated; then the result was spindle-shaped endothelial cell-like morphology. The lectin UEA-I binding and Ac-LDL uptake of the cells were confirmed by fluorescent cells [15] and functional characterization of Dil-ac-LDL uptake and lectin binding resulted percentage of the double-stained cells $70.74 \pm 16.28$ [14].

To determine the cytotoxicity of quercetin, kaempferol, or myricetin, the EPCs were treated using various concentrations of quercetin, kaempferol, or myricetin for $24 \mathrm{~h}$. Cell viability decreased after flavonoid treatment, but there were no significant changes between concentrations 50 to $12.5 \mu \mathrm{mol} / \mathrm{l}$ (table 1 ). EPCs viability decreased up to $26-30 \%$, at the highest flavonoid concentration relative to the negative control (untreated). Flavonoids with concentrate at 12.5 $\mu \mathrm{mol} / \mathrm{l}$ had the lowest point in reducing EPCs viability.

Table 1: Effect quercetin, kaempferol, and myricetin toward cell viability in EPCs

\begin{tabular}{llll}
\hline Sample & Cells viability (\%) & & Myricetin \\
\cline { 2 - 4 } & Quercetin & Kaempferol & $100.00 \pm 6.67^{\mathrm{a}}$ \\
\hline Untreated & $100.00 \pm 6.67^{\mathrm{a}}$ & $100.00 \pm 6.67^{\mathrm{a}}$ & $94.50 \pm 12.91^{\mathrm{a}}$ \\
DMSO & $94.50 \pm 12.91^{\mathrm{a}}$ & $94.50 \pm 12.91^{\mathrm{a}}$ & $94.22 \pm 9.49^{\mathrm{a}}$ \\
$12.5 \mu \mathrm{mol} / \mathrm{l}$ & $96.11 \pm 4.03^{\mathrm{a}}$ & $95.41 \pm 7.75^{\mathrm{a}}$ & $89.86 \pm 12.21^{\mathrm{ab}}$ \\
$25 \mu \mathrm{mol} / \mathrm{l}$ & $93.53 \pm 9.69^{\mathrm{a}}$ & $92.65 \pm 16.05^{\mathrm{a}}$ & $84.08 \pm 14.83^{\mathrm{ab}}$ \\
$50 \mu \mathrm{mol} / \mathrm{l}$ & $90.54 \pm 10.20^{\mathrm{ab}}$ & $86.95 \pm 8.95^{\mathrm{ab}}$ & $70.71 \pm 20.07^{\mathrm{ab}}$ \\
$100 \mu \mathrm{mol} / \mathrm{l}$ & $74.31 \pm 13.61^{\mathrm{b}}$ & $72.46 \pm 5.75^{\mathrm{b}}$ & \\
\hline
\end{tabular}

*Based on Duncan's post-hoc comparisons $(\mathrm{P}<0.05)$, data are presented as mean \pm standard deviation. Different superscripts $(\mathrm{a}, \mathrm{ab}, \mathrm{b})$ in the same column show significant differences among concentrations of flavonoids (quercetin, kaempferol, myricetin).

The results of cytotoxicity tests were calculated using probit analysis, which is logistic regression (method of analyzing the correlation between a stimulus (dose) and the quantal response, then the value of median inhibitory concentration $\left(\mathrm{IC}_{50}\right)$ was determined (table 2). $\mathrm{IC}_{50}$ of kaempferol $(767.50 \mu \mathrm{mol} / \mathrm{l})$ was the highest compared to IC 50 of quercetin $(566.81 \mu \mathrm{mol} / \mathrm{l})$ and myricetin (399.17 $\mu \mathrm{mol} / \mathrm{l})$. Myricetin has the lowest $\mathrm{IC}_{50}$ compared to two other compounds; thus myricetin was the most cytotoxic toward EPCs among flavonoids used in the present study. Three flavonoids compounds were safe on EPCs. 
Table 2: IC50 value of quercetin, kaempferol, and myricetin in EPCs

\begin{tabular}{ll}
\hline Sample & IC $_{\mathbf{5 0}}(\boldsymbol{\mu m o l} / \mathbf{l})$ \\
\hline Quercetin & 566.81 \\
Kaempferol & 767.50 \\
Myricetin & 399.17 \\
\hline
\end{tabular}

The effect of the three flavonoids compounds on oxidative stress was examined. Percentages of ROS level in EPCs significantly increased after $\mathrm{H}_{2} \mathrm{O}_{2}$ induction, compared to the untreated control. The EPCs treated with quercetin, kaempferol, or myricetin has lower ROS level compared to control (untreated) (table 3).

Table 3: Effect quercetin, kaempferol, and myricetin toward ROS level in EPCs

\begin{tabular}{ll}
\hline Sample & ROS level (\%) \\
\hline Untreated & $8.43 \pm 1.59$ a \\
$\mathrm{H}_{2} \mathrm{O}_{2} 200 \mu \mathrm{M}$ & $30.70 \pm 1.04$ c \\
Quercetin $12.5 \mu \mathrm{mol} / \mathrm{l}+\mathrm{H}_{2} \mathrm{O}_{2} 200 \mu \mathrm{M}$ & $14.38 \pm 1.47 \mathrm{ab}$ \\
Kaempferol $12.5 \mu \mathrm{mol} / \mathrm{l}+\mathrm{H}_{2} \mathrm{O}_{2} 200 \mu \mathrm{M}$ & $20.21 \pm 6.25 \mathrm{~b}$ \\
Myricetin $12.5 \mu \mathrm{mol} / \mathrm{l}+\mathrm{H}_{2} \mathrm{O}_{2} 200 \mu \mathrm{M}$ & $13.88 \pm 4.02$ ab \\
\hline
\end{tabular}

*Based on Duncan's post-hoc comparisons $(\mathrm{P}<0.05)$, data are presented as mean \pm standard deviation. Data are presented as mean \pm standard deviation. Different superscripts (a, ab, b, c) in the same column show significant differences among treatment (quercetin, kaempferol, myricetin).

The results showed that flavonols were able to decrease ROS in EPCs. Flavonoid could act as a potent antioxidant because of the combination between chelating activity via ortho-dihydroxy structures, and its ability to scavenge free radicals. There's three stages needed: formation of the hydroxyl radicals $\left({ }^{*} \mathrm{OH}\right)$ and anion superoxide $\left(\mathrm{O}^{*}\right)$ by Fenton's reaction, mechanisms that decrease lipid peroxidation, and formation of lipid radicals [19]. This finding was in line with a previous study where quercetin could protect EPCs from oxidative stress that was induced by high concentration of glucose [16]. Oxidative stress was known to contribute to the progression of cardiovascular disease through known mechanism involving senescence of EPCs [3].

Oxidative stress is known to affect nitric oxide (NO), a key factor that regulates EPCs function. This fact is due to the regulation of endothelial nitric oxide synthetase (eNOS), which was an enzyme that synthesize NO, by ROS [20]. Many polyphenols, such as EGCG, genestein and anthocyanin was reported to enhance NO [21-23].
Polyphenol acts on NO signaling and metabolism, reducing eNOS uncoupling and improving eNOS expression, activity [24].

Consumption of beverage with high content of polyphenolic compound was found to increase circulating EPCs level through the enhancement of NO bioavailability [25]. A previous study found that quercetin induced rapid eNOS phosphorylation through Aktindependent and PKA-dependent mechanism [26]. Increased eNOS activity was demonstrated to prevent apoptosis in EPCs [27]. Thus the protective effect of flavonoid against cellular injury is likely caused by its antioxidant properties and NO promoting activity [28].

The apoptosis assay was measured to know effect of quercetin, kaempferol, and myricetin in EPCs. The EPCs treated with 12.5 $\mu \mathrm{mol} / \mathrm{l}$ of quercetin, kaempferol, or myricetin resulted in similar percentage of apoptotic cells compared to control (table 4.). The lowest percentage of apoptosis was found in EPCs treated with myricetin $(12.07 \pm 3.61 \%)$, but all treatment group was not significantly different among each other.

Table 4: Effect quercetin, kaempferol, and myricetin toward apoptosis in EPCs

\begin{tabular}{ll}
\hline Sample & Apoptosis (\%) \\
\hline Untreated & $13.5 \pm 1.1$ \\
DMSO & $14.4 \pm 1.6$ \\
Quercetin $12.5 \mu \mathrm{mol} / \mathrm{l}$ & $12.4 \pm 1.1$ \\
Kaempferol $12.5 \mu \mathrm{mol} / \mathrm{l}$ & $14.1 \pm 2.2$ \\
Myricetin $12.5 \mu \mathrm{mol} / \mathrm{l}$ & $12.1 \pm 3.6$ \\
\hline
\end{tabular}

*Data are presented as mean \pm standard Deviation. Data was not significant differences among treatment

$\mathrm{H}_{2} \mathrm{O}_{2}$ is one example of ROS that mean when $\mathrm{H}_{2} \mathrm{O}_{2}$ increase the ROS level must be increase too [28-39]. EPCs are characterized based on their cell surface expressions, including CD133, and KDR [1, 14, 15].

This study finding showed that quercetin, kaempferol, and myricetin significantly increased the percentages of KDR expressions but not for CD133 (table 5). EPCs that were treated with quercetin had the highest percentage of KDR $(2.15 \pm 0.54 \%)$ cell population. Whereas myricetin had the highest percentage of CD133 $(0.73 \pm 0.06 \%)$ cell population.

Table 5: Effect quercetin, kaempferol, and myricetin toward CD133, KDR expression in EPCs

\begin{tabular}{lll}
\hline Sample & CD133 (\%) & KDR (\%) \\
\hline Untreated & $0.14 \pm 0.03^{\mathrm{a}}$ & $0.28 \pm 0.02^{\mathrm{a}}$ \\
Quercetin $12.5 \mu \mathrm{mol} / \mathrm{l}$ & $0.19 \pm 0.01^{\mathrm{ab}}$ & $2.15 \pm 0.14^{\mathrm{c}}$ \\
Kaempferol $12.5 \mu \mathrm{mol} / \mathrm{l}$ & $0.16 \pm 0.02^{\mathrm{ab}}$ & $0.77 \pm 0.13^{\mathrm{b}}$ \\
Myricetin $12.5 \mu \mathrm{mol} / \mathrm{l}$ & $0.73 \pm 0.06^{\mathrm{b}}$ & $1.13 \pm 0.16^{\mathrm{b}}$ \\
\hline
\end{tabular}

*Based on Duncan's post-hoc comparisons $(\mathrm{P}<0.05)$, data are presented as mean \pm standard deviation. Data are presented as mean \pm standard seviation. Different superscripts (a, ab, b) in CD133 and (a, b, c) in KDR show significant differences among treatment (quercetin, kaempferol, myricetin)

A previous study showed that EPCs with CD133 expression promoted neovascularization of tissue-engineered constructs in vivo
[30]. Moreover, FACS analysis revealed that KDRof EPCs decreased with a progression to stroke in an animal study, suggesting their 
roles in vascular health for ischemic-hemorrhagic stroke [31]. This study showed that flavonols like quercetin, kaempferol, and myricetin were able to increase the population of cells with important phenotypes in cardiovascular health. Thus, this fact might show the benefit of these common flavonols toward lowering the risk of cardiovascular diseases.

\section{CONCLUSION}

Quercetin, kaempferol, and myricetin were safe for EPCs, decreased ROS level, and increased CD133 and KDR expression. However, the flavonoids did not significantly affect EPCs apoptosis.

\section{ACKNOWLEDGEMENT}

This work was funded from the Ministry of Research and Technology, Indonesia (Ristek Insentif Kapasitas Produksi 2011). The authors gratefully acknowledge to Biomolecular and Biomedical Research Center, Aretha Medika Utama, Bandung, West Java, Indonesia for financial support, laboratory facilities and research method. We also thank to Muhamad Aldi Maulana, Aditya Rinaldy, Cintani Dewi Wahyuni from Aretha Medika Utama Biomolecular and Biomedical Research Center for their valuable assistance.

\section{AUTHORS CONTRIBUTIONS}

All the authors have contributed equally.

\section{CONFLICT OF INTERESTS}

\section{Declared none}

\section{REFERENCES}

1. George AL, Bangalore Prakash P, Rajoria S, Suriano R, Shanmugam A, Mittelman A, et al. Endothelial progenitor cell biology in disease and tissue regeneration. J Hematol Oncol 2011;4:1-50.

2. Werner N, Wassmann S, Ahlers P, Schiegl T, Kosiol S, Link A, et al. Endothelial progenitor cells correlate with endothelial function in patients with coronary artery disease. Basic Res Cardiol 2007;102:565-71.

3. Imanishi $\mathrm{T}$, Tsujioka $\mathrm{H}$, Akasaka T. Endothelial progenitor cells dysfunction and senescence: contribution to oxidative stress. Curr Cardiol Rev 2008:4:275-86.

4. Kirton JP, Xu Q. Endothelial precursors in vascular repair. Microvasc Res 2010;79:193-9.

5. Green DR, Llambi F. Cell death signalling. Cold Spring Harb Perspect Biol 2015;7:1-24.

6. Pizzino G, Irrera N, Cucinotta M, Pallio G, Mannino F, Arcoraci V, et al. Oxidative stress: harms and benefits for human health. Oxid Med Cell Longev 2017:1-13. DOI:10.1155/2017/8416763

7. Van Deursen JM. The role of senescent cells in ageing. Nature 2014:509:439-46.

8. Widowati W, Janeva BW, Nadya S, Amalia A, Arumwardana S, Kusuma HS, et al. Antioxidant and antiaging activities of Jasminum sambac extract, and its compounds. J Rep Pharm Sci 2018;7:270-85.

9. Widowati W, Darsono L, Suherman J, Afifah E, Rizal R, Arinta Y, et al. Mangosteen peel extract (Garcinia mangostana L.) and its constituents to lower lipid content on adipogenesis cells model (3T3-L1). J Nat Remed 2018;18:41-8.

10. Widowati W, Darsono L, Suherman J, Fauziah N, Maesaroh M, Erawijantari PP. Anti-inflammatory effect of mangosteen (Garcinia mangostana L.) peel extract and its compounds in LPS-induced RAW264.7 cells. Nat Prod Sci 2016;22:147-53.

11. Feliciano RP, Pritzel S, Heiss C, Rodriguez Mateos A. Flavonoid intake and cardiovascular disease risk. Curr Opin Food Sci 2015;2:92-9.

12. McCullough ML, Peterson JJ, Patel R, Jacques PF, Shah R, Dwyer JT. Flavonoid intake and cardiovascular disease mortality in a prospective cohort of US adults. Am J Clin Nutr 2012;95:454-64.

13. Asamina K, Gary W. At the interface of antioxidant signalling and cellular function: key polyphenol effects. Mol Nutr Food Res 2016;60:1770-88.

14. Widowati W, Widyanto RM, Husin W, Ratnawati H, Laksmitawati DR, Setiawan B, et al. Green tea extract protects endothelial progenitor cells from oxidative insult through reduction of intracellular reactive oxygen species activity. Iran J Basic Med Sci 2014;17:702-9.

15. Widowati W, Wijaya L, Laksmitawati DR, Widyanto RM, Erawijantari PP, Fauziah N, et al. Tea flavonoids induced differentiation of peripheral blood-derived mononuclear cells into peripheral blood-derived endothelial progenitor cells and suppressed intracellular reactive oxygen species level of peripheral blood-derived endothelial progenitor cells. Nat Prod Sci 2016;22:87-92.

16. Zhao LR, Du YJ, Chen L, Liu ZG, Pan YH, Liu JF, et al. Quercetin protects against high glucose-induced damage in bone marrowderived endothelial progenitor cells. Int $\mathrm{J}$ Mol Med 2014;34:1025-31.

17. Hagiwara $\mathrm{H}$, Higashibata $A$, Ogawa $\mathrm{S}$, Kanazawa $\mathrm{S}$, Mizuno $\mathrm{H}$, Tanaka R. Effectiveness of endothelial progenitor cell culture under microgravity for improved angiogenic potential. Sci Rep 2018;8:1-10.

18. Wlodkowic D, Skommer J, Darzynkiewicz Z. Flow cytometrybased apoptosis detection. Methods Mol Biol 2009;559:19-32.

19. Henneberg R, Otuki MF, Furman AEF, Hermann P, do Nascimento AJ, Leonart MSS. Protective effect of flavonoids against reactive oxygen species production in sickle cell anemia patients treated with hydroxyurea. Rev Bras Hematol Hemoter 2012:35:52-5

20. Fleissner F, Thum T. Critical role of the nitric oxide/reactive oxygen species balance in endothelial progenitor dysfunction. Antioxid Redox Signal 2011;15:933-48.

21. Si H, Yu J, Jiang H, Lum H, Liu D. Phytoestrogen genistein upregulates endothelial nitric oxide synthase expression via activation of cAMP response element-binding protein in human aortic endothelial cells. Endocrinol 2012;153:3190-8.

22. Ahn HY, Kim CH. Epigallocatechin-3-gallate regulates inducible nitric oxide synthase expression in human umbilical vein endothelial cells. Lab Anim Res 2011;27:85-90.

23. Horie K, Nanashima N, Maeda H. Phytoestrogenic effects of blackcurrant anthocyanins increased endothelial nitric oxide synthase (eNOS) expression in human endothelial cells and ovariectomized rats. Molecules 2019;24:1259-70.

24. Forte M, Conti V, Damato A, Ambrosio M, Puca AA, Sciarretta S, et al. Targeting nitric oxide with natural derived compounds as a therapeutic strategy in vascular diseases. Oxid Med Cell Longev 2016:1-20. DOI:10.1155/2016/7364138

25. Huang PH, Chen YH, Tsai HY, Chen JS, Wu TC, Lin FY, et al. Intake of red wine increases the number and functional capacity of circulating endothelial progenitor cells by enhancing nitric oxide bioavailability. Arterioscler Thromb Vasc Biol 2010;30:869-77.

26. Li PG, Sun L, Han X, Ling S, Gan W, Xu JW. Quercetin induces rapid eNOS phosphorylation and vasodilation by an Akt-Independent and PKA-dependent mechanism. Pharmacology 2012;89:220-8.

27. Wen HJ, Liu GF, Xiao LZ, Wu YG. Involvement of endothelial nitric oxide synthase pathway in IGF-1 protects endothelial progenitor cells against injury from oxidized LDLs. Mol Med Rep 2018;19:660-6.

28. Hyun PW. The effects of exogenous $\mathrm{H} 2 \mathrm{O} 2$ on cell death, reactive oxygen species and glutathione levels in calf pulmonary artery and human umbilical vein endothelial cells. Int J Mol Med 2012;31:47-6.

29. Zhang HW, Hu JJ, Fu RQ, Liu X, Zhang YH, Li J, et al. Flavonoids inhibit cell proliferation and induce apoptosis and autophagy through downregulation of $\mathrm{PI} 3 \mathrm{~K} \gamma$ mediated PI3K/AKT/mTOR/p70S6K/ULK signaling pathway in human breast cancer cells. Nat Sci Rep 2018;8:1-13.

30. Herrmann M, Binder A, Menzel U, Zeiter S, Alini M, Verrier S. CD34/CD133 enriched bone marrow progenitor cells promote neovascularization of tissue-engineered constructs in vivo. Stem Cell Res 2014;13:465-77.

31. Decano JL, Moran AM, Giordano N, Ruiz-Opazo N, Herrera VL. Analysis of $\mathrm{CD} 45-[\mathrm{CD} 34+/ \mathrm{KDR}+]$ endothelial progenitor cells as juvenile protective factors in a rat model of ischemichemorrhagic stroke. PLoS One 2013;8:e55222. 